\title{
Light as an indicator of ecological succession in brazilwood (Caesalpinia echinata Lam.)
}

\author{
Liana H. G. Mengarda, Rogério L. F. de Souza', Eliemar Campostrini², Fabrício O. Reis ${ }^{3}$, \\ Wagner A. Vendrame ${ }^{4}$ and Geraldo R. F. Cuzzuol ${ }^{3}$
}

\footnotetext{
${ }^{1}$ Programa de Pós-Graduação em Biologia Vegetal (PPGBV) da Universidade Federal do Espírito Santo (UFES). Av. Fernando Ferrrari 514, Campus Universitário Alaor Queiroz de Araújo, CEP 29075-910 Vitória ES.

E-mail: liana_ya@yahoo.com.br

2 Professor do Setor de Fisiologia Vegetal da Universidade Estadual Norte Fluminense (UENF), Av. Alberto Lamego, CEP 28015620, Campos dos Goytacazes, RJ. E-mail: campost@uenf.br

${ }^{3}$ Professor do Departamento de Ciências Biológicas/CCHN/UFES. Av. Fernando Ferrrari 514, Campus Universitário Alaor Queiroz de Araújo, CEP 29075-910, Vitória ES. E-mail: gcuzzuol@gmail.com.

${ }^{4}$ Associate Professor, Tropical Research and Education Center, IFAS - University of Florida, 18905 SW $280^{\text {th }}$ St, Homestead, FL, 33031, USA. E-mail: vendrame@ufl.edu
}

*Corresponding author: gcuzzuol@gmail.com.

Received: 16 April 2009; Returned for revision: 09 July 2009; Accepted: 14 July 2009

\section{ABSTRACT}

The ecophysiological behavior of brazilwood (Caesalpinia echinata Lam.) plants was evaluated as affected by light quantity and quality. Nine-month-old plants were cultivated under $0 \%, 50 \%$, and $80 \%$ artificial shading, and natural shading imposed by a closed canopy for a period of 392 days. At the end of that period growth parameters were measured, including relative growth rate $(R G R)$, net assimilation rate $(N A R)$, leaf area ratio $(L A R)$, specific leaf mass $(S L M)$ and root:shoot ratio (R:S). Higher leaf area, dry mass and $R G R$ were obtained under $50 \%$ artificial shade. Under full sunlight (0\% shade), growth was satisfactory showing higher R:S and SLM. Growth was inhibited under $80 \%$ artificial and natural shading indicating that $C$. echinata is not pioneer-succession or climax specie. Simulating a gap, plants cultivated under artificial shade $(50 \%)$ were transferred to full sunlight for an interval of $192 \mathrm{~h}$, during which net photosynthesis $(A)$, transpiration $(E)$, stomatic conductance $(g s)$, deficit of pressure vapor (VPDleaf-to-air) and the efficiency quantum potential of photosystem II ( $F v / F m)$ were analyzed. Plants transferred to full sunlight presented severe burning and abscission of the leaflets, as well as inhibition of $A$ and of the photochemical efficiency of PSII $(F v / F m)$. This observation associated with the reduced growth under full sunlight and better performance under moderate shade suggests characteristics of intermediate species.

Key words: chlorophyll fluorescence, gas exchange, growth, light stress, shade, tropical tree.

\section{INTRODUCTION}

The use of tropical native tree species has increased aiming reforestation and this activity depends on data about species regeneration as related to the light gradient. Such information is of great value in defining the position of the species on the forest succession and is essential for the artificial regeneration and management of forests (Kitajima, 1996; Koerselman and Meuleman, 1996; Duz et al., 2004).
Such studies allow the evaluation of physiological plasticity in plants due to environmental factors (Zamith and Scarano, 2004; Lima et al., 2008) and this plasticity is of great importance for conferring stress resistance to plants. This ensures survival and the adequate development of plants in field conditions where environmental factors are adverse.

The knowledge of plant responses to fluctuations in environmental factors is important to determine the best 
possible strategy for restoration of green cover, which is based on the capacity of plants to express their physiological mechanisms with maximum efficiency (Musil et al., 2002; Machado et al., 2005). Therefore, ecophysiological studies can generate important information for conservation and forest restoration, as well as the establishment of in situ and ex situ germoplasm collections, including endangered species as Brazilwood.

Brazilwood (Caesalpinia echinata Lam.) is a tree native to the Brazilian Atlantic Forest with important historical and economical value in Brazil. However, the species is under serious risk of genetic erosion due to intensive exploration associated with the lack of information about its physiological characteristics. The density, flexibility and acoustics of its wood make brazilwood internationally valuable, since it is the ideal raw material for the manufacture of arches for string musical instruments (Franco and Yojo, 2008). Despite its commercial importance, historical and cultural value, and the threat of extinction, little is known about the ecophysiology of this species, a symbol of Brazil.

Current information about the ecological characteristics of brazilwood is quite contradictory. Its classification fits species of rain and semidecidual forests (Lima, 1992; Lorenzi, 2002). There are indications that the species can be an example of tree that needs moderate shade in the juvenile phase, while full development is achieved under full sun when gaps are formed (Carvalho, 1994).

There is a consensus that the light is one of the most important environmental factors for forest establishment (Souza and Válio, 2003a; Duz et al., 2004; Gonçalves et al., 2005). Sunlight irradiance is absorbed by the canopy and just less than $3 \%$ of the light reaches the understorey (Clark et al., 1996). This limits the growth of many plants in the understory due to the low radiation with wave length predominant at 730 nm (Souza and Válio, 2003a).

The movement of canopies due to winds, the abscission of leaves in during dry seasons, and the opening of gaps alter the incidence of radiation and the light quality within the forest (Kitajima, 1996; Minotta and Pinzauti, 1996).

Those alterations in light quality and intensity modify the floristic composition and the morphology of the population of seedlings. They also influence the allocation pattern and biomass partition between root and shoot simultaneously with the net assimilation rate of $\mathrm{CO}_{2}$, relative growth rate and the leaf area ratio (Lambers and Poorter, 1992; Osunkoya et al., 1994; Souza and Válio, 2003a,b). The growth responses due to light can indicate the adaptation ability of species in maximizing the efficient use of nutrients and water in environments with variation of light radiation (Gonçalves et al., 2005).

Lighthas greateffectingas exchange in plants, as indicated by chlorophyll fluorescence. The chlorophyll a fluorescence of FSIl allows a feasible analysis of the quantum potential of photosynthesis efficiency in plants developing under different light conditions (Gonçalves and Santos Jr., 2005). Pigment content and fluorescence chlorophyll a analyses are common stress indicators for excess irradiance (Hendry and Price, 1993). High radiation causes chlorophyll photo-oxidation. In general, trees tend to present better photochemical efficiency $(F v / F m)$ and high chlorophyll concentrations in moderate shade and could present photoprotection mechanisms when cultivated in the full sunlight (Gonçalves et al., 2005).

The lack of information about the position of brazilwood in the ecological succession, its economical importance and its threatened status provide the rationale for further studies. The present study aimed at assessing the effect of light on the growth and photosynthesis in brazilwood. The study of light effects in brazilwood's juvenile phase may provide valuable information to support reforestation programs.

\section{MATERIAL AND METHODS}

Study area and experiment installation: Brazilwood seeds were obtained from FUNBRASIL (Fundação Nacional do Pau Brasil) located in Pernambuco state, Brazil. Seeds were germinated in Petri dishes at $25^{\circ} \mathrm{C}$ (Mello and Barbedo, 2007) in continuous light. On the fifth day after germination, seedlings were transferred to black polyethylene pots $(5 \mathrm{~L})$ containing a mix of dirt and sand (1:1, w/w), with no fertilization added. Plants were maintained under local temperature and photoperiod in a greenhouse located at the Department of Biological Sciences, Espírito Santo University, Vitória city (2018'52" S and 40 $10^{\circ} 06^{\prime \prime}$ W) where the experiments were carried out. The region's climate is tropical humid with an average annual precipitation of $900 \mathrm{~mm}$, average temperature of $24 \pm 2^{\circ} \mathrm{C}$ and photoperiod of $13 \mathrm{~h}$. in the summer and 11 $h$. in the winter. 
After three months of acclimation period, 9-month-old plants were divided into 4 groups of fourteen plants. The first 3 groups were submitted to different shading conditions: 0,50 and $80 \%$ artificial shade provided by neutral screens. The fourth group was placed natural shading provided by a closed canopy near the greenhouse. To avoid heating and loss of water due to soil evaporation, pots under full sunlight ( $0 \%$ shade) were wrapped in aluminum foil and a vermiculite layer was added to the surface of the soil. The photosynthetic active radiation in the different shading conditions and the relationship of red:far-red light ratio (R:Fr) was determined at noon on a sunny day using a spectroradiometer (Spectrum Technologies, Inc., Illinois, USA). The R:Fr was calculated based on the values of irradiance spectrum in the wavelengths of 656-664 nm and 726-734 nm, respectively, with the sensor placed above the plants. During the experiments, plants were watered daily as needed.

Growth analyses: At the beginning of the experiment and 392 days later, brazilwood plants were randomly selected and harvested for initial and final growth evaluations, respectively, including height, number of leaves, leaf area, and dry mass after oven-drying samples at $60^{\circ} \mathrm{C}$ until constant mass. Brazilwood is a species with bipinnate leaves and it has many primary and secondary leaflets. The leaf area total was made by using scanner-generated images (LI-3100C Area Meter, Nebraska, USA). Absolute growth rate $\left(A G R=\left(M_{2}-M_{1}\right)\right)$ $\left.\left(t_{2}-t_{1}\right)\right)$, relative growth rate $\left(R G R=\left(L n M_{2}-L n M_{1}\right) /\left(t_{2}-t_{1}\right)\right)$, net assimilation rate $\left(N A R=\left[\left(D M_{2}-D M_{1}\right) /\left(t_{2}-t_{1}\right)\right] \times\left[\left(1 n A_{2}-1 n A_{1}\right) /\right.\right.$ $\left.\left.\left(A_{2}-A_{1}\right)\right]\right)$, leaf area ratio $(L A R=A L / T D M)$, root:shoot ratio $(R: S)$, specific leaf mass $(S L M=L M / L A)$, leaf mass ratio $(L M R=L M / T M)$, stem mass ratio $(S M R=S M / T D M)$, and root mass ratio $(R M R=R M / D M T)$ were calculated as described by Hunt (1982), where, $M_{1}=$ initial mass; $M_{2}=$ final mass; $t$ $=$ initial time; $t_{2}=$ final time; $A_{1}=$ final leaf area; $A_{2}=$ initial leaf area; $L n=$ natural log; $L M=$ leaf mass, $S M=$ stem mass, $R M=$ root mass, $L A=$ leaf area; $T D M=$ total dry mass.

Gas exchange measurements: Plants cultivated in 50\% shading were transferred to full sun. At 0, 3, 14, 48 and 192 h. after transfer, gas exchange and chlorophyll fluorescence analyses of were performed using the first mid-apical leaves that were completely expanded and the secondary leaflets. Photosynthesis $(A)$, stomatal conductance $\left(g_{s}\right)$, transpiration $(E)$ and vapor pressure deficit (VPDleaf-to-air) were determined using a portable, closed system, infrared gas analyzer (IRGA, model LI-COR 6200, Nebraska, USA). Measurements were performed between 9:00 and 11:00 h. a.m., using the atmospheric $\mathrm{CO}_{2}$ concentration of $1,500 \mu \mathrm{mol}$ $\mathrm{m}^{-2} \mathrm{~s}^{-1}$ as a preliminary value for the curve of $\mathrm{CO}_{2}$. Light curves were obtained for the photosynthetic photon flux density (PPFD) between 0 and $3,000 \mu \mathrm{mol} \mathrm{m} \mathrm{m}^{-2} \mathrm{~s}^{-1}$.

Fluorescence measurements: Chlorophyll fluorescence analysis was performed using a portable fluorometer (Plant Efficiency Analyzer-PEA, Hanstech, King's Lynn, UK). After $30 \mathrm{~min}$. of conditioning in the dark, leaves were exposed to a high intensity saturated light $\left(1,680 \mu \mathrm{mol} . \mathrm{m}^{-2} . \mathrm{s}^{-1}\right)$ pulse for $5 \mathrm{sec}$. at 8:00 h. a.m. From the induction of fluorescence of fast kinetics, the photochemical efficiency of PSII $\left(F_{v} / F_{m}\right)$ was obtained. Water-use efficiency $\left(W U E=\left[\mathrm{mmol} \mathrm{CO}_{2} \cdot \mathrm{mol}^{-}\right.\right.$ $\left.{ }^{1}\left(\mathrm{H}_{2} \mathrm{O}\right)\right]$ ) was calculated by photosynthesis $(A) /$ transpiration $(E)$ ratio and intrinsic water-use efficiency (IWUE $=[\mu \mathrm{mol}$ $\mathrm{CO}_{2} \cdot \mathrm{mol}^{-1} \mathrm{H}_{2} \mathrm{O}$ ) was calculated by the photosynthesis / stomatic conductance $(g s)$ ratio.

Experimental design and statistical analysis: Both experiments used a completely randomized design (CRD) with 7 plants per replication (7 plants harvested at the beginning of the experiment and 7 plants harvested at the end of the experiment, 392 days later). For the second experiment that simulated a gap, 5 plants were used for the gas exchange and chlorophyll fluorescence analyses. Analysis of variance (ANOVA) was used for statistical analysis and means were separated using the Tukey test at $5 \%$ probability level using the software ASSISTAT version 7.4 (Silva and Azevedo, 2007).

\section{RESULTS AND DISCUSSION}

Growth analyses: The different shade conditions did not influence stem length, $L N, P L N$ and SLN, but TLA and ULA were highest under $50 \%$ shade (Table 1). Such results affected $L M$, $S D M$, and TDM production followed by intermediate values under full sunlight and lower $L M$, SDM and TDM production under $80 \%$ artificial and natural shade. Root mass and $S M$ were promoted under $50 \%$ artificial shade (moderate shade) and full sunlight ( $0 \%$ shade). These parameters were most affected under artificial shade (80\%) and natural shade (closed canopy). Consequently, TDM production was promoted by 
moderate shade as compared to full sunlight and densely artificial shade. As for $L D M$ and $S D M$ the values were higher than those measured under densely artificial shade and natural shade (Table 1). Similar results, such as height and number of leaves and leaflets indicate the high plasticity of brazilwood in adapting to different light conditions.

Table 1 - Growth parameters for $C$. echinata after 392 days under different light regimes: height; leaf numbers (LN); primary leaflets numbers (PLN); secondary leaflet number (SLN); total leaf area (TLA); unitary leaf area (ULA); root dry mass (RDM); stem dry mass (SDM); leaf dry mass (LDM); shoot dry mass (ShootDM) e total dry mass $(T D M)$. Numbers represent means \pm standard error $(n=7)$. Different letters indicate significant differences at 0.05 by Tukey’s test.

\begin{tabular}{|c|c|c|c|c|c|c|c|c|c|c|c|}
\hline \multirow{2}{*}{ Shade } & \multirow{2}{*}{$\begin{array}{l}\text { Height } \\
\text { (cm) }\end{array}$} & \multirow{2}{*}{$L N$} & \multirow{2}{*}{$P L N$} & \multirow{2}{*}{$S L N$} & TLA & ULA & $R D M$ & SDM & $L D M$ & ShootDM & $T D M$ \\
\hline & & & & & \multicolumn{2}{|c|}{$\left(\mathrm{cm}^{2}\right)$} & \multicolumn{5}{|c|}{ (g) } \\
\hline $0 \%$ & $50 \pm 3,8 \mathrm{a}$ & $12 \pm 0,9 a$ & $83 \pm 6,4 \mathrm{a}$ & $846 \pm 82 a$ & $5522 \pm 260 b$ & $06,5 \pm 0,51 b$ & $22 \pm 2,87 \mathrm{a}$ & $11,7 \pm 0,93 a$ & $14 \pm 0,87 b$ & $26 \pm 1,73 b$ & $47 \pm 4,13 b$ \\
\hline $50 \%$ & $68 \pm 1,7 \mathrm{a}$ & $11 \pm 0,9 a$ & $75 \pm 4,3 \mathrm{a}$ & $833 \pm 48 a$ & $9876 \pm 286 a$ & $11,8 \pm 0,64 a$ & $22 \pm 1,28 \mathrm{a}$ & $13,5 \pm 0,63 a$ & $18 \pm 0,96 \mathrm{a}$ & $32 \pm 1,52 \mathrm{a}$ & $54 \pm 2,35 \mathrm{a}$ \\
\hline $80 \%$ & $51 \pm 1,5 \mathrm{a}$ & $15 \pm 0,8 \mathrm{a}$ & $112 \pm 9,3 \mathrm{a}$ & $1199 \pm 125 \mathrm{a}$ & $5514 \pm 580 b$ & $04,6 \pm 0,87 b$ & $04,2 \pm 0,36 b$ & $04,1 \pm 0,18 b$ & $10 \pm 0,62 c$ & $14 \pm 0,74 \mathrm{c}$ & $18 \pm 1,05 c$ \\
\hline Natural & $44 \pm 4,2 \mathrm{a}$ & $11 \pm 1,4 a$ & $67 \pm 8,2 \mathrm{a}$ & $626 \pm 88 a$ & $4674 \pm 610 b$ & $07,5 \pm 0,55 b$ & $04,4 \pm 0,33 \mathrm{~b}$ & $04,4 \pm 0,44 b$ & $09 \pm 0,90 \mathrm{c}$ & $13 \pm 1,26 c$ & $18 \pm 1,53 c$ \\
\hline
\end{tabular}

The lower LA and ULA under $80 \%$ shade and natural shade might have been influenced by low light and also by the lower $R$ :Fr, particularly under natural shade where the ratio was $24 \%$ smaller as compared to full sunlight. Reduced leaf area is one of the responses evoked by phytochromes under low R:Fr ratio (Smith and Whitelam, 1990; Souza and Válio, 2003a).

Stem elongation under natural shade, as expected, did not occur because of the low source-sink interactions under restricted photosynthetic photon flux under natural shade. Under similar conditions, reduced photosynthesic rate can limit the capacity of stem elongation, regulated by the low R:Fr ratio (Bartlett and Remphrey, 1998).

Reports on the ecological characteristics of brazilwood as related to light are controversial (Carvalho, 1994; Lorenzi, 2002). For example, 8-year-old trees grown in the city of Domingos Martins, Espírito Santo state, Brazil (20²1'49" S and $40^{\circ} 39^{\prime} 33^{\prime \prime} \mathrm{W}$ ), in a slope receiving direct sunlight in the morning, averaged $6.60 \mathrm{~m}$ in height while another lot of the same age in the same location, but grown inside the forest did not exceed $1.50 \mathrm{~m}$ (Mengarda, personal observation). The limited growth inside the forest associated with the low performance of brazilwood grown under $80 \%$ artificial shade and natural shade (Table 1) confirms that this tropical tree cannot be considered an early or late-successional species. In fact brazilwood has characteristics of intermediate species and present better growth under moderate shade ( $50 \%$ shade). Chazdon (1992) indicates that plants in this succession category have high growth potential and can express maximum growth potential under moderate irradiance.

Furthermore, besides light, climate and topography are additional environmental factors of great importance for plant growth and cell metabolism. Brazilwood may respond differently to light variation according to the particular environmental conditions under which it develops. While the climate of Vitória city varies from tropical dry to tropical humid, the city of Domingos Martins is situated at altitude of $400 \mathrm{~m}$, and has a tropical mountain climate.

Brazilwood under full sunlight showed similar pattern to that observed under $50 \%$ artificial shade, such as higher values of $D M R$ which reflected in the highest $R: S$ ratio on conditions of higher light intensity (Table 2). Tropical trees under shade tend to allocate more biomass for the root system in response to increase in irradiance intensity to the detriment of shoots (Osunkoya et al., 1994; Souza and Válio, 2003a; Duz et al., 2004; Gonçalves et al., 2005). This adaptive strategy reduces the loss of water through leaf transpiration, thus helping maintenance of the metabolic processes at high temperature and irradiance. In fact, higher $R M R$ and smaller $L M R$ were verified in brazilwood plants under 0 and $50 \%$ shade (Table 2), thus supporting this premise. However, one should take into account that most luminous radiation is associated with higher temperatures and which together may affect the growth in intermediate species as observed by Rondon et al. (2006) in brazilwood of plants grown in elevated temperatures. 
Leaf analyses are considered a key factor for ecophysiological studies because the effects of environmental disturbances reflect on the morphological and physiological characteristics of leaves (Lambers and Poorter, 1992). Plants that grow under low light incidence usually show higher specific leaf area (SLA), and succulent and thin leaves (Evans and Poorter, 2001; Souza and Válio, 2003a,b), while those that grow under high irradiance present smaller leaf area and higher SLM, with thick leaves and sclerophylly. Thus, the most sensitive measures to the environmental variations are SLA and SLM.

Table 2 - Ratio and growth rate of $C$. echinata after 392 days under different light regimes: Root:shoot ratio (R:S); specific leaf mass (SLM); specific leaf area (SLA); root mass ratio $(R M R)$; stem mass ratio $(S M R)$; leaf mass ratio $(L M R)$; leaf area ratio $(L A R)$; absolute growth rate $(A G R)$; relative growth rate $(R G R)$ e net assimilatory rate $(N A R)$. Numbers represent means \pm standard error $(n=7)$. Different letters indicate significant differences at 0.05 by Tukey's test.

\begin{tabular}{|c|c|c|c|c|c|c|c|c|c|c|}
\hline Shade & $\mathrm{R}: \mathrm{S}$ & $\begin{array}{c}S L M \\
\left(\mathrm{mg} \mathrm{cm}-{ }^{2}\right)\end{array}$ & $\begin{array}{c}S L A \\
\left(\mathrm{~cm}^{2} \mathrm{mg}^{-1}\right)\end{array}$ & $\begin{array}{l}R M R \\
\left(g^{-1}\right)\end{array}$ & $\begin{array}{l}S M R \\
\left(g^{-1}\right)\end{array}$ & $\begin{array}{l}L M R \\
\left(g^{-1}\right)\end{array}$ & & & $\begin{array}{c}R G R \\
\left(\mathrm{mg} \mathrm{g}^{-1} \mathrm{~d}^{-1}\right)\end{array}$ & $\begin{array}{c}N A R \\
\left(\mathrm{mg} \mathrm{cm}^{-2} \mathrm{dia}^{-1}\right)\end{array}$ \\
\hline & & & & & & & & & & \\
\hline $50 \%$ & $0,69 \pm 0,04 \mathrm{a}$ & $1,86 \pm 0,7 b$ & $0,54 \pm 0,04 \mathrm{a}$ & $0,41 \pm 0,01 \mathrm{a}$ & $0,25 \pm 0,01 \mathrm{a}$ & $0,34 \pm 0,01 b$ & $182 \pm 0 \mathrm{c}$ & $0,13 \pm 0,01 \mathrm{a}$ & & $0,036 \pm 0 \mathrm{a}$ \\
\hline $80 \%$ & $0,30 \pm 0,02 b$ & $1,81 \pm 1,0 \mathrm{~b}$ & $0,55 \pm 0,05 \mathrm{a}$ & $023+001 \mathrm{~h}$ & $0,22 \pm 0,01 \mathrm{a}$ & $0,54 \pm 0,01 \mathrm{a}$ & $301 \pm 0 \mathrm{a}$ & $0,03 \pm 0,00 \mathrm{~b}$ & $3,78 \pm 0 b$ & $0,013 \pm 0 \mathrm{~b}$ \\
\hline Natural & $0,33 \pm 0,02 \mathrm{~b}$ & $1,90 \pm 1,0 \mathrm{~b}$ & $0,53 \pm 0,06 \mathrm{a}$ & $0,25 \pm 0,01 b$ & $0,25 \pm 0,01 \mathrm{a}$ & $0,50 \pm 0,02 \mathrm{a}$ & $264 \pm 0 \mathrm{~b}$ & $0,03 \pm 0,00 \mathrm{~b}$ & $3,70 \pm 0 b$ & $0,014 \pm 0 \mathrm{~b}$ \\
\hline
\end{tabular}

Brazilwood plants cultivated under full sunlight presented higher SLM and, consequently, smaller SLA (Table 2), suggesting that this species fits well under high sun radiation, thus developing thickening of the leaf mesophyll evidenced by higher SLM values. This reduces the damages in leaves by exposure to high radiation and reduces the loss of water, thus ensuring good photosynthetic performance (Nakazono et al., 2001). High SLA values under low radiation are an indicative of better use of the low radiation reaching the plant (Files et al., 2008) confirming that brazilwood has physiological characteristics of intermediate species in contrast to early or late-successional species.

In addition to the low SLM and smaller $R: S$ ratio under low irradiation, plants tend to present higher $L A R$ under similar conditions (Poorter, 1999). Brazilwood plants cultivated under $80 \%$ shade presented higher LAR followed by intermediate values under natural shade, and smaller value under full sunlight (Table 2). It has been shown that many tropical trees grown under shade demonstrate higher LAR (Souza et al., 2003a; Lima et al., 2008).

Although $L A R$ can be directly related to relative growth rate $(R G R)$ (Poorter and Nagel, 2000; Souza and Válio, 2003a), highest $L A R$ in brazilwood plants under $80 \%$ artificial and natural shade was not associated to $R G R$ (Table 2). Also, a positive correlation exists between $S L M$ and the photosynthetic rate besides being directly related to $R G R$, (Poorter and Nagel, 2000).
Brazilwood plants under $80 \%$ and natural shade presented smaller $L D M$ due to lower NAR. The highest $R G R$ and $N A R$ of brazilwood under moderate shade $(50 \%)$ and full sunlight suggests that this species has characteristics of intermediate or early-successional. However, the smaller leaf area production and TDM under full sunlight contrasts this hypothesis. To verify this, the $L A, S L M$, and TDM as well as $A G R, R G R$ and NAR analyses (Table 2) showed moderate shade to be ideal for the initial growth of brazilwood.

Based on the lowest values of shoot mass under density shade ( $80 \%$ and natural shade), brazilwood cannot be classified as late-successional or climax species. The ability to tolerate moderate shade during the juvenile phase indicates that some species, such as the brazilwood could complete their development when the opening of gap happens (Whitmore, 1990). Low growth rate under high levels of shade ( $80 \%$ and natural shade) demonstrate lower capacity of brazilwood in developing under density shade and this can be associated to lowest photosynthetic efficiency under conditions of low or intensive photon rate.

Photosynthesis: In the experiment that simulates an artificial gap, plants that were transferred to full sunlight and those that remained under moderate shade showed a decrease in $\mathrm{CO}_{2}$ assimilation at $48 \mathrm{~h}$ after the beginning of the treatment. However, the values of $A$ were always higher in the plants under moderate shade. This reduction of $A$ during the first $48 \mathrm{~h}$ may be due to environmental variations, such as temperature, 
irradiance, and relative humidity (Oliveira et al., 2002; Costa and Marenc0, 2007; Dias and Marenco, 2007). In plants transferred to full sunlight, the photosynthesis rate decreased progressively until $192 \mathrm{~h}$, a time in which the shaded plants are recovering the photosynthetic capacity (Figure $1 \mathrm{~A}$ ).
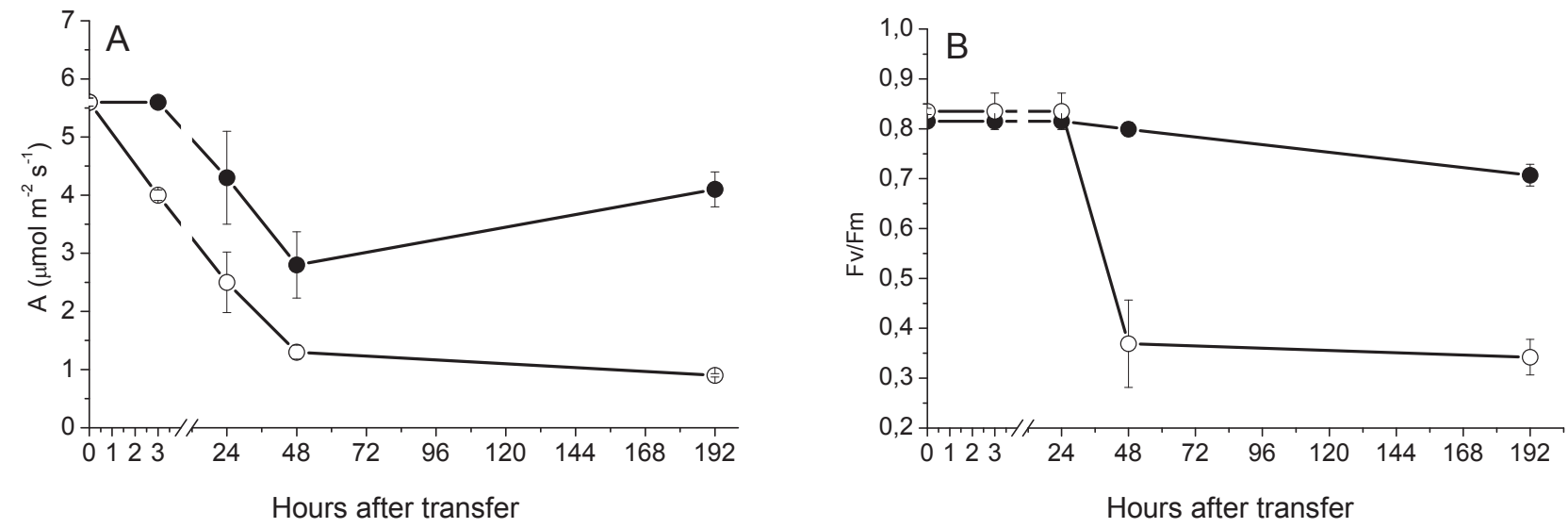

Figure 1. (A) Photosynthetic carbon assimilation (A) and (B) photosynthetic potential efficiency (Fv/Fm) of C. echinata plants subjected to constant artificial shade of $50 \%(O)$ and transferred from shade to full sunlight $(O)$ at 0, 3, 24, 48 and $192 \mathrm{~h}$. after the start of the experiment. Vertical bars indicate standard error $(n=5)$.

Although the carbon assimilation rate usually presents a lineal increase as a function of the light intensity, high irradiancy can limit the photosynthetic assimilation of $\mathrm{CO}_{2}$ due to dissipation energy mechanisms, such as photorespiration and photoinhibition (Dias and Marenco, 2007; Costa and Marenco, 2007). Photoinhibition and oxidation of chlorophyll in brazilwood exposed to full sunlight could be evidenced by burning and chlorosis of leaflets after $72 \mathrm{~h}$ of exposure to the direct sun radiation as shows the physiognomic leaflets aspects of the $C$. echinata (Figure 4).

The stomatic conductance ( $g s$ ) followed a similar pattern as for $A$, however, the damage from exposure to full sunlight started dropping quickly by the third hour, reaching the lowest values at $192 \mathrm{~h}$ (Figure 2A). Under moderate shade, the $g$ s followed the behavior observed for the photosynthesis rate. The transpiration rate $(E)$ suffered a fast reduction under full sunlight already at the third hour of exposure and it increased simultaneously with the plants on moderate shade, however, without significant difference (Figure 2B). Afterwards, plants from both treatments showed progressive reduction in $A$ until the end of the experiment. Plants showed increase in VPDleaf-to-air, at $24 \mathrm{~h}$ followed by a decrease until $192 \mathrm{~h}$, with higher values for the plants that were transferred to direct sun radiation (Figure 2C).

The reduction in photosynthetic rate associated to the increase in VPDleaf-to-air and reduction of $g s$ has been shown to occur possibly due to the increase of time of exposure to the light and temperature (Dias and Marenco, 2007). High VPDleaf-to-air can cause closing of the stomata, decrease of the internal carbon concentration and, consequently, reduction in photosynthesis. For brazilwood plants transferred to direct sun radiation it was observed an increase in VPDleaf-to-air and gradual reduction of $A$ during the $192 \mathrm{~h}$ of direct sun exposure. 


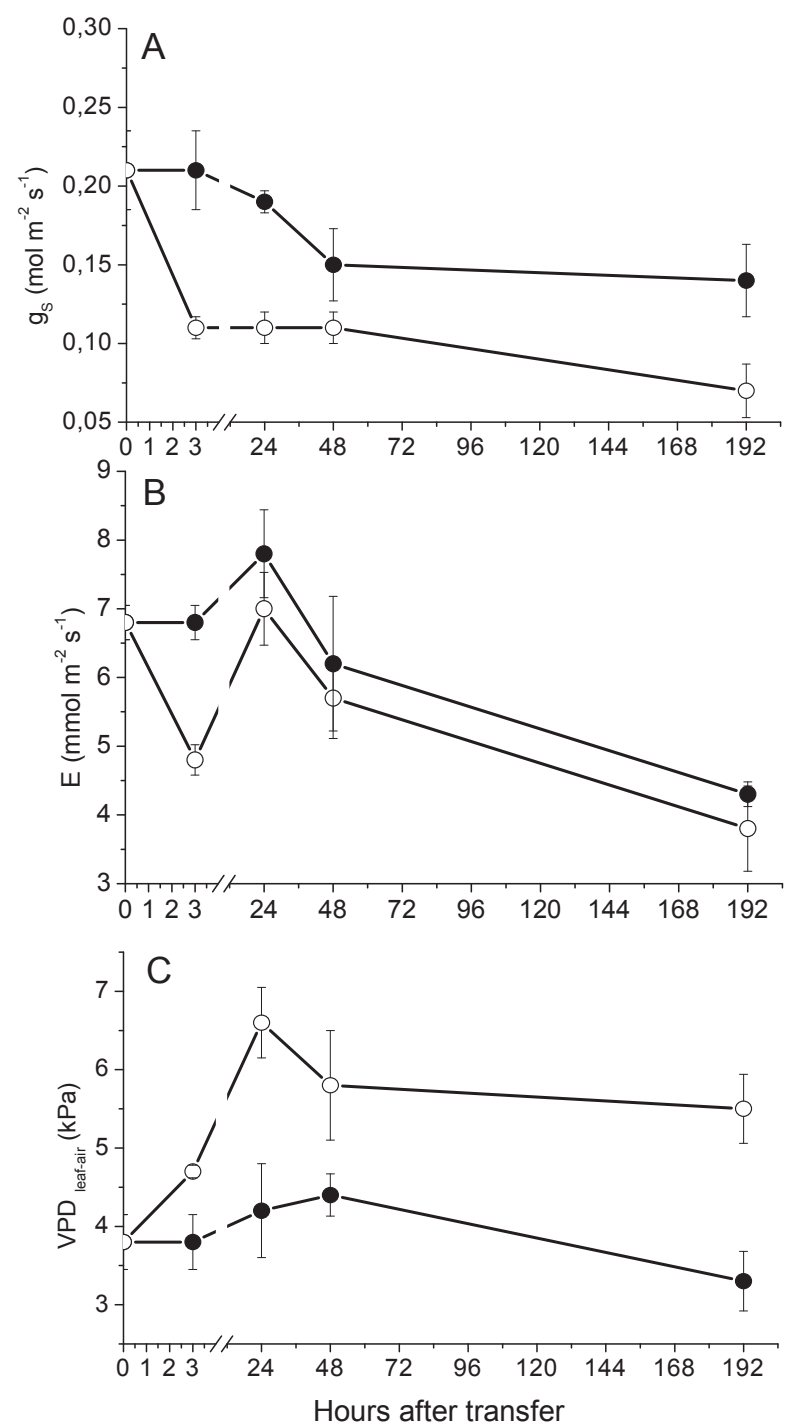

Figure 2. (A) Stomatic conductance $\left(g_{S}\right)$, (B) transpiration $(E)$, and $(C)$ vapor pressure deficit $\left(V P D_{\text {leat-air }}\right)$, of $C$. echinata plants subjected to constant artificial shade of $50 \%(\bullet)$ and transferred from shade to full sunlight $(O)$ at $0,3,24,48$ and $192 \mathrm{~h}$. after the start of the experiment. Vertical bars indicate standard error $(n=5)$.

The fast reduction of $E$ in the first $3 \mathrm{~h}$ of exposure to sunlight as related to net photosynthetic rate is an indicative of an efficient mechanism of adaptation aiming to control the reduction of loss of water (Oliveira et al., 2002; Cavalcante and Conforto, 2006). This can be confirmed by the reduction of WUE associated to the decreasing values of $A$ during the first $48 \mathrm{~h}$ after transfer to sunlight, after which differences intensified up to $192 \mathrm{~h}$ (Figure 3A). Some tropical tree species, such as Aniba roseadora has shown a relative decrease in WUE when subjected to high light intensity (Gonçalves et al., 2005). Similar results were also observed for IWUE (Figure 3B) demonstrating that brazilwood limits water-use when exposed to direct sun radiation due to the partial closing of the stomata (Figure 2A).
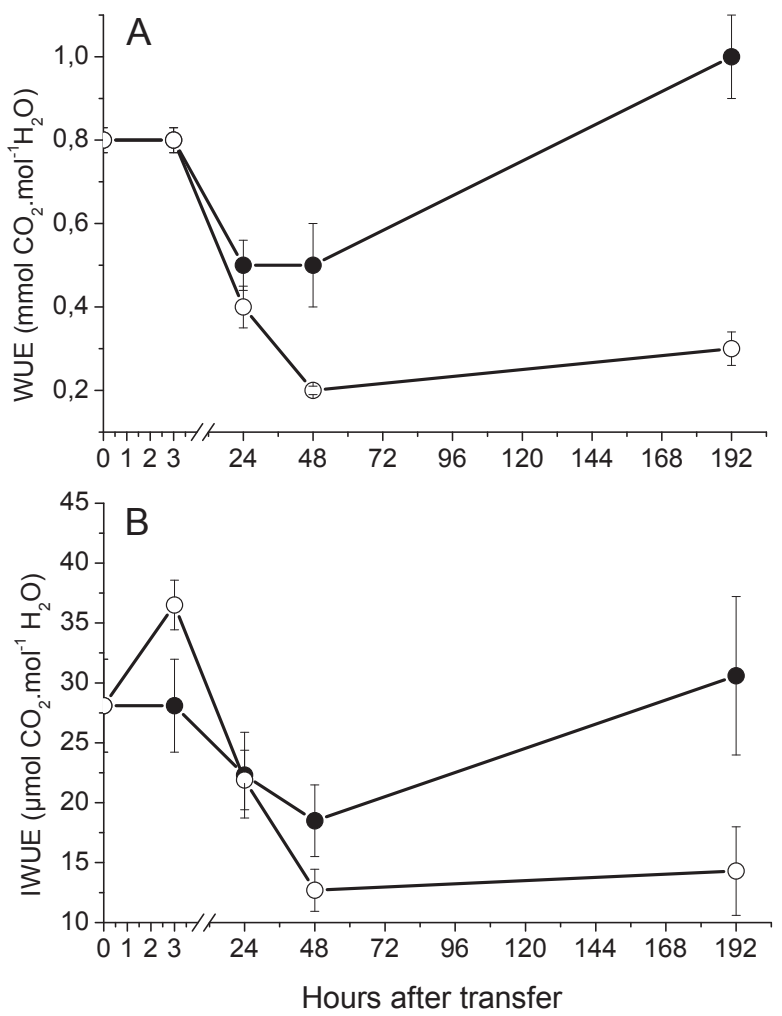

Figure 3. (A) Water-use efficiency (WUE) and (B) intrinsic water-use efficiency (IWUE) of $C$. echinata plants subjected to constant artificial shade of $50 \%(\mathbf{O})$ and transferred from shade to full sunlight $(O)$ at $0,3,24,48$ and $192 \mathrm{~h}$. after the start of the experiment. Vertical bars indicate standard error $(n=5)$.

$2,5 \mathrm{~cm}$

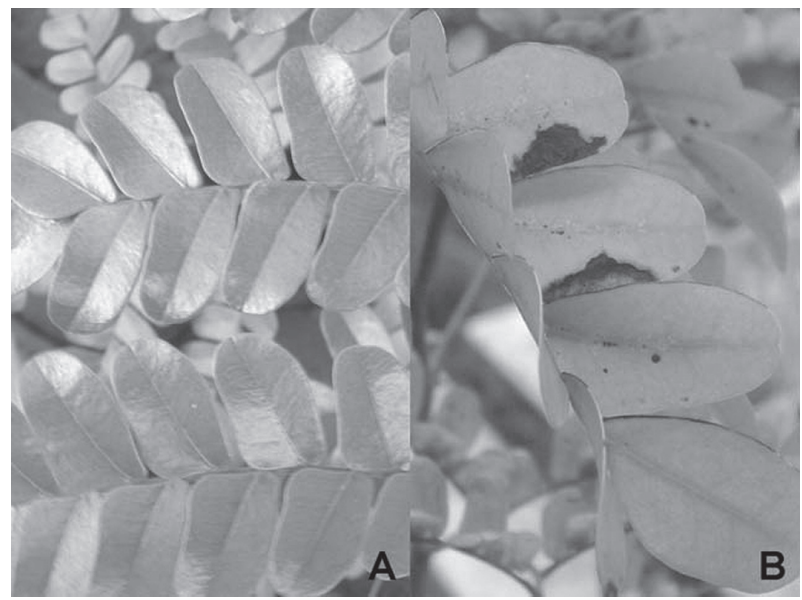

Figure 4. Physiognomic leaflets aspects of the $C$. echinata plants subjected to $50 \%$ of artificial shade constant (A) and after the transfer to full sunlight (B). Leaflets of all plants show burn and marginal chlorosis at $72 \mathrm{~h}$ after the transfer to full sunlight $(n=5)$. 
The exposure of young plants to direct light can intensify the photoinhibition effects caused mainly by the increase in leaf temperature and drastic decrease in leaf hydric potential, which directly affects gs and $E$ (Valladares and Pearcy, 1997). Photoinhibition can be evidenced from measures of chlorophyll fluorescence, which expresses the maximum quantum efficiency of $P S / I$ or the Fv/Fm ratio (Butler, 1978; Björkman, 1987).

Plants exposed to full sunlight as well as that under moderate shade showed no variation for $F v / F m$ for the first $24 \mathrm{~h}$ of the experiment. The ratio varied from 0.700 to 0.815 (Figure 1B), similar to values found by Gebler et al. (2005) in adult plants of $C$. echinata. After $24 \mathrm{~h}$ we noticed a sharp drop in the quantum efficiency of $P S / l$ in plants under full sunlight; $50 \%$ lower than the value found in plants subjected to moderate shade at $192 \mathrm{~h}$. Reductions in the $\mathrm{Fv} / \mathrm{Fm}$ ratio have been related to photoinhibition induction as reported for tropical trees subjected to irradiancy increases (Dias and Marenco, 2007) and plants exposed to several environmental stresses that affect the PSII functionality (Long et al., 1994; Rohacek and Bartak, 1999). Indeed, exposure of leaves to intense light can damage the $D 1$ protein of $P S / l$ interfering in the electron transport, and thus can reduce the effectiveness of the photochemistry phase of the photosynthesis (Gonçalves and Santos Jr., 2005).

The succession stage can influence photosynthesis and photochemistry efficiency potential of plants when exposed to direct light or in a gap. In fact, some tropical tree has shown reduction in $\mathrm{Fv} / \mathrm{Fm}$ in gaps present in semi-deciduous forests (Brook et al., 2004). However, species that are sun tolerant make better use of the light energy and are capable of dissipating the excess of energy as compared to shade tolerant species. Consequently, we can assume that gas exchange and fluorescence of chlorophyll a of $C$. echinata are less efficient in use of the energy under direct light. This can result in structural and physiologic damages causing the reduction of $A, g s, E$ and increase in VPDleaf-to-air.

Given the short evaluation period, it was possible to identify the signaling phase of the light stress of $A$ and gs already in the first hour, which continued up to $192 \mathrm{~h}$ of exposure to direct sun radiation. Based on the results with young plant, brazilwood appears to be an intermediate species because it establishes better under conditions of moderate shade (50\% artificial shade). This species cannot be considered early or late-successional because it shows to be not density shade-tolerant $(80 \%$ artificial shade and natural shade) neither full sunlight-tolerant. The classification of young brazilwood plants as intermediate can be confirmed by inhibition of photosynthesis under the gap simulated full sunlight (Figure 1A,B). Furthermore, latesuccessional species comprise the species usually found in the density shaded understory, whereas early-successional species comprise the species that are absent from large gaps or forest edges (Souza and Válio, 2003a). Therefore, the results confirm that young brazilwood plants could be intermediate species because they occur under conditions of moderate shade, such as in small gaps, shaded forest edges or moderately shaded understory, as observed in its area of natural occurrence. To further confirm these observations, the natural shade simulated under close canopy caused reduction in both PPFD and $R / F r$ ratio, where by some of the brazilwood was influenced by light quality and quantity.

In contrast, plants under simulated gaps were affected by full sunlight (Tables 1, 2). Plant growth under natural shade was more affected than under artificial density shade $(80 \%$ shade). This might reflects a high sensitivity of $C$. echinata to light quality and quantity. When full sunlight reaches the canopy it is filtered reducing both PPFD and R/Fr (Souza and Válio, 2001, 2003). Only early-successional species can tolerate these conditions. The intolerance of brazilwood to the density shaded understory and the inhibitory effects on photosynthesis (Figures 1A, B) associated to reduced growth (Tables 2,3) allows us to classify this species as intermediate. This suggestion is supported by its natural habitat of seasonal semideciduous forests and slow growth occurring in soils of Brazilian Atlantic Forest between Rio Grande do Norte and Rio de Janeiro State (Gebler et al. 2005).

The reduced $L N$ might be a phytochrome response under conditions of reduced $R$ :Fr ratio (Smith and Whitelam, 1990). However, the effects on $L N$ and on stem height under natural simulation of closed canopy show that brazilwood does not have a typical morphogenetic response of late-successional species. Additional evidence is the higher RGR and NAR on lower shade (Table 2).

Possibly brazilwood plants developing under a natural gap can find the satisfactory conditions for rustification. This can ensure better conditions for growth and raise the percentage of survival for recruitment of seedlings for reforestation using 
native tropical species. Analysis of soluble carbohydrates and amino acids associated with light stress may help in understanding the physiological mechanisms of brazilwood under the effect of high-radiation stress. The present data will enable to place this species in adequate position in ecological succession, which is very important for management and reforestation programs.

Acknowledgements: We thank Fundação Biodiversitas, Fundação de Apoio à Pesquisa do Espírito Santo (FAPES) and Fundo de Apoio Científico e Tecnológico da Prefeitura Municipal de Vitória (FACITEC) for the financial support to this work. Thanks also to FACITEC for the assistantship provided.

\section{REFERENCES}

Bartlett GA, Remphrey WR (1998) The effect of reduced quantities of photosynthetically active radiation on Fraxinus pennsylvanica growth and architecture. Can. J. Bot. 76:1359-1365.

Björkman 0 (1987) Fluorescence in leaves and its relationship to photon yield of photosynthesis in photoinhibition. In: Kyle DJ, Osmond CB, Arntzen CJ (eds), Photoinhibition, pp.123. Elsevier Publishers, Amsterdam, The Netherlands.

Butler WL (1978) Energy distribution in the photochemical apparatus of photosynthesis. Ann. Rev. Plant Physiol. 29: 345-378.

Carvalho PER (1994) Espécies florestais brasileiras: recomendações silviculturais, potencialidades e uso da madeira. Embrapa-CNPF/SPI, Brasília, Brasil.

Cavalcante JR, Conforto EC (2006) Fotossíntese e relações hídricas de duas cultivares jovens de seringueira. Rev. Bras. Bot. 29: 701-708.

Chazdon RL (1992) Photosynthetic plasticity of two rain forest shrubs across natural gap transects. Oecologia 92: 586-595.

Clark DB, Clark DA, Rich PM, Weis SE, Oberbauer SF (1996) Landscape-scale evaluation of understorey light and canopy structure: methods and application in a neotropical lowland rain forest. Can. J. For. Res. 26: 747-757.

Costa GF, Marenco RA (2007) Fotossíntese, condutância estomática e potencial hídrico foliar em árvores jovens de andiroba (Carapa guianensis). Acta Amazonica 37: 229-234.

Dias DP, Marenco RA (2007) Fotossíntese e fotoinibição em mogno e acariquara em função da luminosidade e temperatura foliar. Pesq. Agropec. Bras. 42: 305-311.

Duz SR, Siminski A, Santos M, Paulilo MTS (2004) Crescimento inicial de três espécies de arbóreas da floresta atlântica em resposta a variação na quantidade de luz. Rev. Bras. Bot. 27: 587-596.

Evans JRE, Poorter H (2001) Photosynthetic acclimation of plants to growth irradiance: the relative importance of specific leaf area and nitrogen partitioning in maximizing carbon gain. Plant Cell Environ. 24: 755-767.

Franco N, loyo T (2008) Propriedades físicas, mecânicas e acústicas da madeira do pau-brasil. In: Figueiredo-Ribeiro RCL, Barbedo CJ, Alves ES, Domingos M, Braga MR (eds), Pau-Brasil, da Semente à Madeira, pp. 145158. Instituto de Botânica, São Paulo, Brasil.

Gebler A, Duarte HM, Franco AC, Lüttge U, Mattos EA, Nahm M, Rodrigues PJEP, Scarano FR, Rennenberg H (2005) Ecophysiology of selected tree species in different plant communities at the periphery of the Atlantic Forest of SE - Brazil III. Three legume trees in a semi-deciduos dry forest. Trees 19: 523-530.

Gonçalves JFC, Santos Jr UM (2005a) Utilization of the chlorophyll a fluorescence technique as a tool for selecting tolerant species to environments of higth irradiance. Braz. J. Plant Physiol. 17: 307-313.

Gonçalves JFC, Barreto DCS, Santos Jr UM, Fernandes AV, Sampaio PTB, Buckeridge MS (2005b) Growth, photosynthesis and stress indicators in young rosewood plants (Aniba rosaeodora Ducke) under different light intensities. Braz. J. Plant Physiol. 17: 325-334.

Hendry GAF, Price AH (1993) Stress indicators: chlorophylls and carotenoids. In: Hendry GAF, Grime JP (eds), Methods in Comparative Plant Ecology, pp. 148-152. Chapman \& Hall, London, UK.

Hunt R (1982) Plant growth curves: the functional approach to plant growth analysis. Edward Arnold Publishers, London, UK.

Kitajima K (1996) Ecophysiology of tropical tree seedlings. In. Mulkey SS, Chazdon RL, Smith AP (eds), Tropical forest plant ecophysiology, pp 559595.Chapman \& Hall, New York, USA.

Koerselman W, Meuleman AFM (1996) The vegetation N:P ratio: a new tool to detect the nature of nutrient limitation. J.Applied Ecol. 33:1441-1450.

Lambers H, Poorter H (1992) Inherent variation in growth rate between higher plants: a search for physiological causes and ecology consequences. Adv. Ecol. Res. 23: 187-261.

Lichtenthaler HK (1996) Vegetation stress: an introduction to the stress concept in plants. J. Plant Physiol. 148: 4-14.

Lima HC (1992) Aspectos botânicos do pau-brasil. In: Cunha MW, Lima HC (eds), Viagem à terra do pau-brasil, pp 23-38. Agência Brasileira de Cultura, Rio de Janeiro, Brasil.

Lorenzi H (2002) Árvores brasileiras: manual de identificação e cultivo de plantas arbóreas do Brasil. $2^{\text {th }}$ ed. Plantarum, São Paulo, Brasil.

Lima JD, Silva BMS, Moraes WS, Dantas VAV, Almeira CC (2008) Efeitos da luminosidade no crescimento de Caesalpinia ferrea Mart. ex Tul. (Leguminosae, Caesalpinoideae). Acta Amazônica 38: 5-10.

Machado EC, Schimidt PT, Medina CL, Ribeiro RV (2005) Respostas da fotossíntese de três espécies de citros a fatores ambientais. Pesq. Agropec. Bras. 40: 1161-1170.

Mello JI0, Barbedo, CJ (2007) Temperatura, luz e substrato para germinação de sementes de pau-brasil (Caesalpinia echinata Lam., Leguminosae. Caesalpinioideae). Revista Árvore, 31: 645-655.

Minotta G, Pinzauti S (1996) Effects of light and soil fertility on growth, leaf chlorophyll content and nutrient use efficiency of beech (Fagus sylvatica L.) seedlings. For. Ecol. Manag. 86:61-67.

Musil CF, Chimphango SBM, Dakora FD (2002) Effects of elevated ultraviole-B radiation on native and cultivated plants of southern Africa. Ann. Bot. 90: 127-137.

Nakazono EM, Costa MC, Futatsugi K, Paulino MTS (2001) Crescimento inicial de Euterpe edulis Mart. em diferentes regimes de luz. Rev. Bras. Bot. 24: $173-179$

Osunkoya 00, Ash JE, Hopkins MS, Graham AW (1994) Influence of seed size and seedling ecological attributes on shade-tolerance in northen Queensland. J. Ecol. 82:149-163.

Oliveira MAJ, Bovi ML, Machado EC, Gomes MMA, Habermann G, Rodrigues JD (2002) Fotossíntese, condutância estomática e traspiração em pupunheira sob deficiência hídrica. Sci. Agric. 59: 59-63.

Poorter L (1999) Growth responses of 15 rain-forest tree species to a light gradient: the relative importance of morphological and physiological traits. Funct. Ecol. 13: 396-410.

Poorter $\mathrm{H}$, Nagel $\mathrm{O}$ (2000) The role of biomass allocation in the growth response of plants to different levels of light, $\mathrm{CO2}$, nutrients and water: a quantitative review. Aust. J. Plant Physiol. 27: 595-607. 
Rondon JN, Zaidan, LBP, Domingos M, Barbedo, CJ, Figueiredo-Ribeiro, RCL (2006) Vegetative responses to temperatura and photoperiod in saplings of brazilwood (Caesalpinia echinata Lam., Leguminosae). Braz. J. Plant Physiol. 18(4): 467-474.

Silva FAS, Azevedo CAV (2007) A new version of the Assistat-Statistical Assistance Software. In: World Congress on computers in agriculture 4. Orlando, USA, pp. 393-396.

Smith H, Whitelam GC (1990) Phytochrome, a family of photoreceptors with multiple physiological roles. Plant Cell Environ.13: 695-707.

Souza RP, Válio IFM (2003a) Seedling growth of fifteen brazilian tropical tree species differing in sucessional status. Rev. Bras. Bot. 26: 35-47.
Souza RP, Válio IFM (2003b) Leaf optical properties as affected by shade in saplings of six tropical tree species differing in successional status. Braz. J. Plant Physiol. 15: 49-54.

Valladares F, Percy RW (1997) Interactions between water stress, sun-shade acclimation, heat tolerance and photoinhibition in the selerophyll Heteromeles arbutifolia. Plant Cell Environ. 20: 25-36.

Withmore TC (1990) An introuduction to tropical rain Forest. Claredon Press, Oxford.

Zamith LR, Scarano FR (2004) Produção de mudas de espécies das restingas do município do Rio de Janeiro, RJ, Brasil. Acta Bot. Bras. 18:161-176. 